\title{
Phomopsis Dieback: A Grapevine Trunk Disease Caused by Phomopsis viticola in California
}

J. R. Úrbez-Torres, Department of Plant Pathology, University of California, Davis, CA 95616; F. Peduto, Department of Plant Pathology, University of California, Davis, CA 95616; R. J. Smith, University of California Cooperative Extension, Sonoma County, Santa Rosa, CA 95403; and W. D. Gubler, Department of Plant Pathology, University of California Davis, Davis, CA 95616

\begin{abstract}
Úrbez-Torres, J. R., Peduto, F., Smith, R. J., and Gubler, W. D. 2013. Phomopsis dieback: A grapevine trunk disease caused by Phomopsis viticola in California. Plant Dis. 97:1571-1579.

Field surveys recently conducted in California and in other grapegrowing regions in the United States showed Phomopsis viticola to be one of the most prevalent fungi isolated from grapevine perennial cankers in declining vines. The current study has not only confirmed the presence of $P$. viticola from grapevine cankers in California but also has for the first time revealed the occurrence of Diaporthe ambigua, $D$. eres, and D. neotheicola in symptomatic grapevine wood in California by means of morphological studies and multi-gene sequence analysis. Pathogenicity trials conducted on mature cordons of Vitis vinifera 'Syrah' and 'Red Globe', as well as on lignified Syrah dormant canes, showed $P$. viticola isolates from California to be capable of causing perennial cankers. Lengths of vascular discoloration caused by $P$. viticola were similar to those caused by Eutypa lata and several Botry-

osphaeriaceae spp., which are well-known grapevine trunk disease pathogens. Additionally, a lack of spring growth was commonly observed in dormant canes inoculated with $P$. viticola spore suspensions in two pathogenicity trials. As part of this study, V. vinifera 'Cabernet Sauvignon' and 'Zinfandel' wood was shown to be more susceptible to infection by $P$. viticola than 'Barbera', 'Chardonnay', 'Merlot', and 'Thompson Seedless' wood. After more than 40 years overlooking $P$. viticola as a grapevine wood pathogen, this study provides strong evidence of the role of $P$. viticola as a canker-causing organism, and suggests its addition to the fungi involved in the grapevine trunk disease complex. Results from this study suggest $D$. ambigua and $D$. neotheicola to be saprophytes or weak pathogens on grapevine wood.
\end{abstract}

Phomopsis (Sacc.) Bubák (teleomorph: Diaporthe Nitschke) is a cosmopolitan fungal genus that contains both plant pathogens and endophytes described from a wide range of annual and perennial hosts, including economically important crops $(18,55)$. Since Phomopsis was established as fungal genus by Saccardo in 1905 (45), over 900 species have been described (44). This large proliferation of species names has primarily been a consequence of the fact that most of the species were characterized by host affiliation (55). Presently, however, it is well-accepted that the same Phomopsis species can be found on different hosts and that more than one species can occur on the same host. Consequently, host association is no longer considered relevant in the taxonomy of this genus and its Diaporthe teleomorphs $(30,43)$. Moreover, plasticity of morphological characters in these genera makes identification to species difficult (43). Accordingly, Phomopsis and Diaporthe species are currently identified primarily by molecular phylogenies $(12,46,47$, 53,61).

Phomopsis viticola (Sacc.) Sacc. is historically known to infect grapevines (Vitis vinifera and Vitis spp.) causing Phomopsis cane

Corresponding author: W. D. Gubler,

E-mail:wdgubler@ucdavis.edu

Current address of J. R. Úrbez-Torres: Agriculture and Agri-Food Canada, Pacific Agri-Food Research Centre, 4200 Highway 97, Box 5000, Summerland, British Columbia VOH1Z0, Canada.

Current address of F. Peduto: Department of Plant Pathology, Ohio State University, Columbus, $\mathrm{OH} 43210$.

* The $\boldsymbol{e}$-Xtra logo stands for "electronic extra" and indicates that Figures 1 and 2 appear in color online.

Accepted for publication 9 May 2013.

http://dx.doi.org/10.1094/PDIS-11-12-1072-RE

(C) 2013 The American Phytopathological Society and leaf spot disease (22). Although $P$. viticola occurs wherever grapes are grown (18), Phomopsis cane and leaf spot is more severe in grape-growing regions characterized by a humid temperate climate through the growing season. Crop losses up to $30 \%$ have been reported to be caused by Phomopsis cane and leaf spot $(16,37)$. $P$. viticola can infect all green parts of the grapevine, and thus disease symptoms can be observed on leaves as small palegreen to yellow spots with necrotic centers. Canes show brown to black necrotic irregular-shaped lesions, and clusters show rachis necrosis and brown, shriveled berries close to harvest (22). Phomopsis cane and leaf spot is a well-studied grapevine disease, and much has been written about its etiology $(30,31,36,48)$, epidemiology $(16,17,22,33,37)$, and management $(11,15,19,32,37)$.

However, $P$. viticola has not always been associated exclusively with Phomopsis cane and leaf spot symptoms. In 1909, P. viticola (syn. Fusicoccum viticolum Reddick) was originally associated with a syndrome named "necrosis of the grapevine" in the state of New York (41), which was renamed dead-arm disease of grapes a few years later $(42,49)$. Although some of the dead-arm disease symptoms first described by Reddick in 1909 (41) were in agreement with what is currently known as Phomopsis cane and leaf spot, the author also associated $P$. viticola with other symptoms, including lack of spring growth, shoot dieback, short shoot internodes, small leaves crimped about the margin, and fruit shrivel in mid- to late-summer, all of which could be observed on one or both cordons. A few years later, Reddick observed that most of the vines affected by the dead-arm disease also presented sectorial necrosis in the vascular system when cross-sections were made in cordons and/or trunks (42). From the early 1920s to the mid-1960s, deadarm disease was reported to occur in almost all grape-growing regions in the eastern United States and Canada $(2,3,5,9,10,65)$, California (21), Japan (23), and South Africa (13). Proof of pathogenicity of $P$. viticola on grapevine wood was also reported $(9,42)$. However, studies on grapevines worldwide during the 1970s led to the discovery of the diatrypaceous fungus Eutypa lata (Pers.) Tul. \& C. Tul. (syn. Eutypa armeniacae Hansf. \& M.V. Carter). This fungus was thus subsequently associated with some of the dead- 
arm disease symptoms such as stunted shoots with small, chlorotic, and distorted leaves, and perennial cankers in the wood $(14,25,27,28)$. Such research caused the scientific community to reconsider the role that $P$. viticola played in this syndrome. By the end of the 1970s, the association of E. lata with this symptomatology was evident and proof of pathogenicity was established (28). These studies led scientists to conclude that E. lata and not $P$. viticola incited dead-arm disease symptoms of grapevines (29). Since then, $P$. viticola has been strictly considered the causal agent of Phomopsis cane and leaf spot.

Nevertheless, field surveys conducted between 2003 and 2006 in California revealed $P$. viticola to be the third most prevalent fungus isolated from grapevine cankers ( $7 \%$ recovery) after species in the Botryosphaeriaceae and Diatrypaceae families. Moreover, $P$. viticola was the main fungal pathogen isolated from grapevine cankers, with $26 \%$ recovery in the southern San Joaquin Valley (59). More recently, studies conducted in grape-growing regions of Arkansas, Missouri, and Texas showed P. viticola to be among the most prevalent fungi, isolated from 6 to $15 \%$ of grapevine cankers $(57,60)$. Furthermore, $P$. viticola was recently reported from grapevine perennial cankers in grape-growing regions in the northeastern United States (4). The frequent recovery of $P$. viticola from perennial cankers has again raised the question whether this fungus plays a role in grapevine dieback originally reported by Reddick in 1909 (41). This study was undertaken to identify and characterize the morphological features, multi-locus phylogeny, and pathogenicity of the different Phomopsis spp. isolated from grapevine cankers in California in order to determine whether or not $P$. viti-

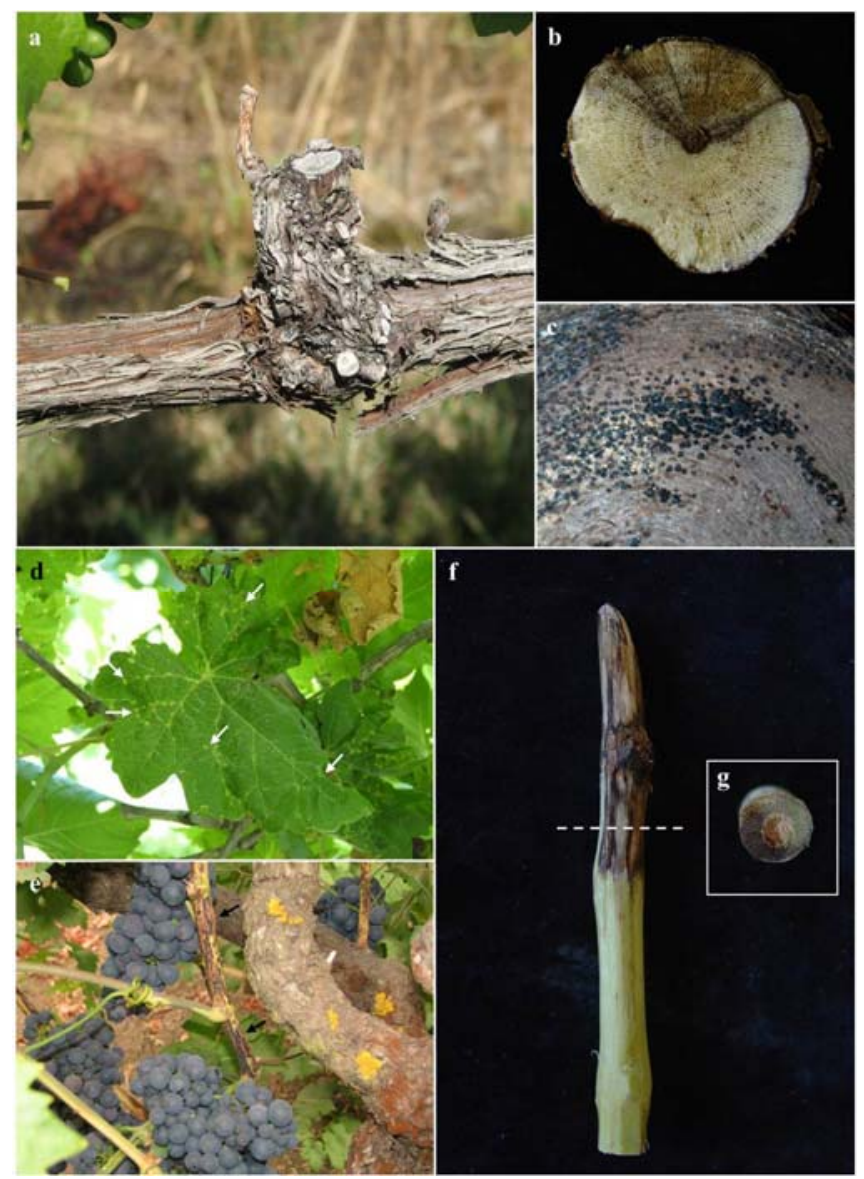

Fig. 1. Grapevine symptoms associated with Phomopsis viticola in California. a, A lack of spring growth at the spur position. $\mathbf{b}$, Wedge-shape perennial cankers in the cordon. c, Black, flask-shape pycnidia of $P$. viticola on the cordon of a declining vine. $\mathbf{d}$ and $\mathrm{e}$, Phomopsis cane and leaf spot symptoms. $d$, White arrows point to small pale-green to yellow spots with necrotic center on leaves. e, Black arrows point dark-brown to black necrotic irregular-shaped lesions on shoots. f, Vascular discoloration caused by P. viticola isolate UCD115Fr on a 'Syrah' dormant cane. $\mathbf{g}$, Wedge-shape lesion observed in the cross section. cola should also be considered as a fungal grapevine trunk disease pathogen.

\section{Materials and Methods}

Phomopsis isolates. The majority of the isolates used in this study were collected from perennial cankers observed in spur positions, cordons, and/or trunks from grapevines showing characteristic dieback symptoms during field surveys conducted between 2003 and 2006 throughout all grape-growing regions of California (59) (Fig. 1a to c). Additionally, seven isolates obtained between 2006 and 2010 from grapevine cankers and/or vines showing Phomopsis cane and leaf spot symptoms submitted to our laboratory by University of California Cooperative Extension Viticulture Farm Advisors and pest control advisors were also included in the study (Fig. 1d and e). Phomopsis isolates from symptomatic grapevine tissue were isolated as described by Úrbez-Torres et al. (59). They were tentatively identified to genus based on both colony and conidium morphological characters, and stored in the Plant Pathology Department fungal collection at the University of California, Davis. Pure cultures from the collection were grown on $85-\mathrm{mm}-$ diameter petri dishes containing $4 \%$ potato dextrose agar (PDA) (Difco Laboratories, Detroit, MI) amended with tetracycline hydrochloride $(0.01 \%)$ (Sigma-Aldrich, St. Louis, MO) at room temperature $\left(24^{\circ} \mathrm{C} \pm 2{ }^{\circ} \mathrm{C}\right)$ until fungal colonies were observed. Colonies were then transferred onto fresh PDA and incubated unsealed under ambient laboratory conditions of light and temperature, followed by identification to species based on morphology and molecular analyses.

DNA extraction, amplification, and phylogenetic analyses. Representative isolates of the different Phomopsis spp. previously identified based on morphological characters were selected for molecular identification (Table 1). Total genomic DNA was extracted from 2-week-old PDA cultures using the AquaPure Genomic DNA Kit (Bio-Rad Laboratories, Hercules, CA). Oligonucleotide primers ITS1 and ITS4 and EF1-728F and EF1-986R were used to amplify the ITS1-5.8S-ITS2 gene (ITS) and part of the translation elongation-factor $1-\alpha$ gene $(E F 1-\alpha)$, respectively $(6,63)$. Each polymerase chain reaction (PCR) was comprised of 5 $\mu \mathrm{l}$ of $10 \times$ PCR buffer containing $15 \mathrm{mM} \mathrm{MgCl}_{2}, 2 \mu \mathrm{l}$ of $25 \mathrm{mM}$ $\mathrm{MgCl}_{2}, 1 \mu \mathrm{l}$ of $10 \mathrm{mM}$ dNTPs, $2 \mu \mathrm{l}$ of $0.5 \mathrm{mM}$ of each primer, 0.25 $\mu \mathrm{l}$ of Taq DNA polymerase (Taq PCR core kit; Qiagen, Valencia, CA) at 5 units $/ \mu 1$, and $2 \mu$ of DNA template adjusted with purified water (Water Systems; Millipore, Billerica, MA) to a final volume of $50 \mu$ l. PCR reactions were carried out in a thermal cycler (PTC 200; M. J. Research Company, Watertown, MA) following previously described ITS (63) and EF1- $\alpha$ (6) temperature profiles. Amplification products were purified using the QIAquick PCR purification kit (Qiagen). Both strands of the ITS and EF1- $\alpha$ were sequenced using an ABI Prism 377 DNA Sequencer (PerkinElmer, Norwalk, CN) at the Division of Biological Sciences sequencing facility at the University of California, Davis.

Fungal sequences were edited and assembled using Sequencher version 4.1 (Gene Codes, Ann Arbor, MI) and aligned using the software BioEdit Sequence Alignment Editor Version 7.1.3.0 (20). Alignments were checked and adjusted manually where necessary. Sequences of Phomopsis and Diaporthe spp. from grapevine and other hosts, including ex-type specimens identified in previous studies and available in GenBank, were included in the phylogenetic analyses (Table 2). Separate phylogenetic analyses were performed on individual ITS and EF1- $\alpha$ datasets (individual trees are not illustrated), and tree topologies were compared. Phylogenetic analysis of the ITS and EF1- $\alpha$ combined datasets was inferred in MEGA5 (51) by Neighbor-Joining (NJ) using the Maximum Composite Likelihood method and by Maximum Parsimony (MP) using the heuristic search option with 1,000 random addition sequence replicates and the Close-Neighbor-Interchange (CNI) algorithm. Alignment gaps were treated as missing data and all characters were unordered and equally weighted. Tree length, consistency index $(\mathrm{CI})$, retention index (RI), and rescaled consistency index (RC) were calculated in the MP method. Bootstrap support was 
estimated using 1,000 replicates to assess the robustness of each clade in both phylogenetic methods. Phomopsis and Diaporthe fungal sequences from grapevine from California were deposited into GenBank, and representative isolates are maintained in the collection of the Plant Pathology Department at the University of California, Davis (Table 1).

Inoculum preparation. Three different pathogenicity experiments were conducted using either mycelium plugs or conidial suspensions from each of the isolates selected (Table 1). Conidial suspensions of approximately $1 \times 10^{5}$ conidia/ml were obtained as described by Úrbez-Torres and Gubler (58). Mycelium inoculations were conducted using 5-mm-diameter mycelium plugs harvested from the active colony edge of 2-week-old cultures. Two out of the three experiments (mature wood cordon and 'Syrah' dormant cane inoculations) were part of a broader study conducted to determine the pathogenicity of Botryosphaeriaceae spp. on grapevines (58).

Mature wood cordon inoculations. $P$. viticola isolate UCD1935SB was used in this experiment (Table 1). Pathogenicity tests were independently conducted in a 14-year-old Syrah vineyard located at the University of California, Kearney Agricultural Research and Extension Center in Parlier, CA and in a 7-year-old 'Red Globe' vineyard at the University of California Field Station in Davis, CA. Vines in both vineyards were cordon trained and spur pruned. Fifteen-day-old mycelium plugs were used to inoculate mature wood cordon tissue. Inoculations were conducted at the end of the cordon between the last two spur positions by drilling a hole 10 to $15 \mathrm{~mm}$ deep using a 5-mm-diameter electric drill. Wounds were immediately inoculated by placing a mycelial plug in the hole, sealed with petroleum jelly, and wrapped with Parafilm (Pechiney, Chicago, IL). Noncolonized agar plugs were used as a negative control. Ten cordons (one cordon per vine) were inoculated in each Syrah and Red Globe vineyard in January and February of 2006, respectively, in a completely randomized design. Cordons were collected 24 months after inoculation. Cordons were disinfected, sectioned longitudinally through the point of inoculation, and length of vascular discoloration recorded both upward and downward from the point of inoculation. Koch's postulates were fulfilled by reisolation of the fungus by placing 10 small pieces of symptomatic tissue from the edge of each lesion on PDAtet. Identification of the reisolated fungus was assessed by morphological comparison to the original isolate UCD1935SB. Both pathogenicity trials also included isolates of the grapevine trunk disease pathogens E. lata and Botryosphaeriaceae spp. (58). In order to determine the significance of $P$. viticola as a grapevine trunk disease pathogen, its mean length of vascular discoloration

Table 1. Diaporthe and Phomopsis species isolated from Vitis vinifera wood cankers and Phomopsis cane and leaf spot in California vineyards between 2005 and 2010

\begin{tabular}{|c|c|c|c|c|c|c|c|}
\hline \multirow[b]{2}{*}{ Species } & \multirow[b]{2}{*}{ Isolate number ${ }^{t}$} & \multirow{2}{*}{$\begin{array}{l}\text { Origin/ } \\
\text { Date collected }^{u}\end{array}$} & \multirow[b]{2}{*}{ Symptom $^{v}$} & \multirow[b]{2}{*}{ Cultivarw } & \multirow[b]{2}{*}{ Collector } & \multicolumn{2}{|c|}{ GenBank acc. numbers } \\
\hline & & & & & & ITS $^{x}$ & EF1- $\alpha^{y}$ \\
\hline D. ambigua & UCD1151Na & $\begin{array}{l}\text { Napa Co./ } \\
09 / 2009\end{array}$ & Canker in cordon & $\begin{array}{l}\text { Cabernet } \\
\text { Sauvignon }\end{array}$ & J.R. Úrbez-Torres & KF017908 & KF017890 \\
\hline D. ambigua & UCD2076Te & $\begin{array}{l}\text { Riverside Co./ } \\
05 / 2005\end{array}$ & Canker in cordon & Chardonnay & J.R. Úrbez-Torres & KF017909 & KF017891 \\
\hline D. ambigua & UCD2078Te & $\begin{array}{l}\text { Riverside Co./ } \\
05 / 2005\end{array}$ & Canker in cordon & Chardonnay & J.R. Úrbez-Torres & KF017910 & KF017892 \\
\hline D. ambigua & UCD2079Te & $\begin{array}{l}\text { Riverside Co./ } \\
05 / 2005\end{array}$ & Canker in cordon & Sangiovese & J.R. Úrbez-Torres & KF017911 & KF017893 \\
\hline D. ambigua & UCD2114Te & $\begin{array}{l}\text { Riverside Co./ } \\
05 / 2005\end{array}$ & Canker in cordon & Sangiovese & J.R. Úrbez-Torres & KF017912 & KF017894 \\
\hline D. eres & UCCE993A & $\begin{array}{l}\text { Sonoma Co./ } \\
03 / 2010\end{array}$ & Canker in cordon & Pinot Noir & R. J. Smith & KF017913 & KF017895 \\
\hline D. eres & UCCE1004B & $\begin{array}{l}\text { Sonoma Co./ } \\
04 / 2010\end{array}$ & Soft-rotted wood & Chardonnay & R. J. Smith & KF017914 & KF017896 \\
\hline D. neotheicola & UCCE993B & $\begin{array}{l}\text { Sonoma Co./ } \\
03 / 2010\end{array}$ & Canker in cordon & Pinot Noir & R. J. Smith & KF017915 & KF017897 \\
\hline D. neotheicola & UCD2327Mar & $\begin{array}{l}\text { Marin Co./ } \\
06 / 2007\end{array}$ & Canker in cordon & Pinot Noir & J.R. Úrbez-Torres & KF017916 & KF017898 \\
\hline D. neotheicola & UCD2328Mar & $\begin{array}{l}\text { Marin Co./ } \\
06 / 2007\end{array}$ & Canker in cordon & Pinot Noir & J.R. Úrbez-Torres & KF017917 & KF017899 \\
\hline D. neotheicola & UCD2329Mar & $\begin{array}{l}\text { Marin Co./ } \\
06 / 2007\end{array}$ & Canker in cordon & Pinot Noir & J.R. Úrbez-Torres & KF017918 & KF017900 \\
\hline P. viticola & UCD115Fr & $\begin{array}{l}\text { Fresno Co./ } \\
11 / 2003\end{array}$ & Canker in cordon & Grenache & J.R. Úrbez-Torres & KF017919 & KF017901 \\
\hline P. viticola & UCD1935SB & $\begin{array}{l}\text { Santa Barbara Co./ } \\
05 / 2005\end{array}$ & Canker in cordon & Chenin Blanc & J.R. Úrbez-Torres & KF017920 & GU294704 \\
\hline P. viticola & UCD1938SB & $\begin{array}{l}\text { Santa Barbara Co./ } \\
05 / 2005\end{array}$ & Canker in cordon & Chenin Blanc & J.R. Úrbez-Torres & KF017921 & GU294705 \\
\hline P. viticola & UCD2009SB & $\begin{array}{l}\text { Santa Barbara Co./ } \\
05 / 2005\end{array}$ & Canker in cordon & Chardonnay & J.R. Úrbez-Torres & KF017922 & GU294706 \\
\hline P. viticola & UCCE964A & $\begin{array}{l}\text { Sonoma Co./ } \\
09 / 2009\end{array}$ & Bleached cane ${ }^{\mathrm{z}}$ & Zinfandel & R. J. Smith & KF017923 & KF017902 \\
\hline P. viticola & UCCE964B & $\begin{array}{l}\text { Sonoma Co./ } \\
09 / 2009\end{array}$ & Bleached cane ${ }^{z}$ & Zinfandel & R. J. Smith & KF017924 & KF017903 \\
\hline P. viticola & UCCE964C & $\begin{array}{l}\text { Sonoma Co./ } \\
09 / 2009\end{array}$ & Bleached cane ${ }^{z}$ & Zinfandel & R. J. Smith & KF017925 & KF017904 \\
\hline P. viticola & UCCE964D & $\begin{array}{l}\text { Sonoma Co./ } \\
09 / 2009\end{array}$ & Bleached cane ${ }^{z}$ & Zinfandel & R. J. Smith & KF017926 & KF017905 \\
\hline
\end{tabular}


caused in each cultivar was separately compared with those caused by the well-known grapevine canker pathogens E. lata and Botryosphaeriaceae species from the same trials and previously published (58).

Syrah dormant cane inoculations. $P$. viticola isolates UCD1935SB, UCD1938SB, and UCD115Fr were used in this experiment (Table 1). The field trial was conducted in the same 14year-old Syrah vineyard located at Kearney Agricultural Research and Extension Center. Grapevines were pre-pruned to 8- to 10-bud short canes in January 2006, and fresh pruning wounds were immediately inoculated by applying $50 \mu \mathrm{l}$ of a $1 \times 10^{5}$ conidia $/ \mathrm{ml}$ suspension from each isolate as described by Úrbez-Torres and Gubler (58). Control treatments were inoculated by applying $50 \mu \mathrm{l}$ of sterile distilled water. Each treatment was applied onto one 1year-old dormant cane per grapevine on each of 10 grapevines in a completely randomized design. Treatments also included three isolates of E. lata (DHB100, DCA200, and UCD783St) as positive controls (52). E. lata dormant cane inoculations were conducted by applying an ascospore suspension from each isolate as described by Trouillas and Gubler (52). Canes were collected 13 months after inoculation, surface disinfected, and sectioned longitudinally. The extent of vascular discoloration was measured from the point of inoculation as previously described. Koch's postulates were fulfilled by reisolation of the fungus from infected tissue as described above. This pathogenicity trial also included isolates of the grapevine trunk disease pathogens Botryosphaeriaceae spp. (58). As described in the cordon pathogenicity test, the mean length of vascular discoloration caused by the $P$. viticola isolates was compared with those caused by the well-known grapevine canker pathogens E. lata and Botryosphaeriaceae spp. from the same trial. Mean lengths of vascular discoloration caused by species of Botryosphaeriaceae from this trial were published in 2009 (58).

Grapevine cultivar susceptibility to infection by $P$. viticola and Diaporthe spp. $P$. viticola isolates UCD115Fr, UCCE964A, and UCD1935SB; D. ambigua isolates UCD1151Na and UCD2079Te; and D. neotheicola isolate UCD2327Mar were used in this study (Table 1). Six different grapevine cultivars were tested, including Barbera, Cabernet Sauvignon, Chardonnay, Merlot, and Zinfandel (cordon trained and spur pruned) located at the Kearney Agricultural Research and Extension Center and Thomp-

Table 2. Diaporthe and Phomopsis species used in the phylogenetic analyses

\begin{tabular}{|c|c|c|c|c|c|c|}
\hline \multirow[b]{2}{*}{ Species } & \multirow[b]{2}{*}{ Isolatew $^{w}$} & \multirow[b]{2}{*}{ Host } & \multirow[b]{2}{*}{ Origin } & \multirow[b]{2}{*}{ Collector } & \multicolumn{2}{|c|}{ GenBank acc. numbers ${ }^{v}$} \\
\hline & & & & & $\operatorname{ITS}^{\mathbf{x}}$ & EF1- $\alpha^{y}$ \\
\hline D. alleghaniensis & CBS 495.72 & Betula alleghaniensis & Ontario, Canada & R.H. Arnold & FJ889444 & GQ250298 \\
\hline D. ambigua & CBS 114015 & Pyrus communis & South Africa & S. Denman & AF230767 & GQ250299 \\
\hline D. ambigua & CBS 117374 & Aspalathus linearis & South Africa & J.C.J. van Rensburg & DQ286237 & DQ286268 \\
\hline D. ambigua & CBS 123210 & Foeniculum vulgare & Portugal & J.M. Santos & EU814479 & GQ250300 \\
\hline D. ambigua & CBS 123211 & F. vulgare & Portugal & J.M. Santos & EU814478 & GQ250301 \\
\hline D. ambigua & CPC 5423 & A. linearis & South Africa & J.C.J. van Rensburg & DQ286247 & DQ286273 \\
\hline D. angelicae & CBS 111592 & Heracleum sphondylium & Austria & W. Jaklitsch & AY196779 & GQ250302 \\
\hline D. aspalathi & CBS 117169 & A. linearis & South Africa & J.C.J. van Rensburg & DQ286275 & DQ286249 \\
\hline D. crotalariae & CBS 162.33 & Crotalaria spectabilis & North America & G.F. Weber & FJ889445 & GQ250307 \\
\hline D. eres & Pho12 & $V$. vinifera & New York, USA & P. Rolshausen & JN214572 & JN192166 \\
\hline D. eres & Pho27 & $V$. vinifera & Connecticut, USA & P. Rolshausen & JN214586 & JN192180 \\
\hline D. eres & Pho30 & $V$. vinifera & Quebec, Canada & P. Rolshausen & JN214589 & JN192183 \\
\hline D. eres & Pho31 & $V$. vinifera & Quebec, Canada & P. Rolshausen & JN214590 & JN192184 \\
\hline D. helianthi & CBS 592.81 & Helianthus annus & Serbia & M. Muntanola-Cvetkovic & AY705842 & GQ250308 \\
\hline D. hickoriae & CBS 145.26 & Carya glabra & Michigan, USA & L.E. Wehmeyer & FJ889446 & GQ250309 \\
\hline D. lusitanicae & CBS 123212 & F. vulgare & Portugal & J.M. Santos & EU814477 & GQ250310 \\
\hline D. melonis & CBS 507.78 & Cucumis melo & Texas, USA & L. Beraha \& M.J. O’Brien & FJ889447 & GQ250314 \\
\hline D. neotheicola & CBS 123208 & F. vulgare & Portugal & A.J.L. Phillips & EU814480 & GQ250315 \\
\hline D. neotheicola & CBS 123209 & F. vulgare & Portugal & A.J.L. Phillips & GQ250192 & GQ250316 \\
\hline D. neotheicola & $\mathrm{Ph}-\mathrm{C} 182 / 1$ & Acer negundo & Portugal & A.J.L. Phillips & GQ250195 & GQ250319 \\
\hline D. perjuncta & CBS 109745 & Ulmus glabra & Austria & W. Jaklitsch & AY485785 & GQ250323 \\
\hline D. phaseolorum & CBS 127266 & H. annus & Croatia & K. Vrandečić & HM347707 & HМ347672 \\
\hline D. phaseolorum & PS03 & Glycine $\max$ & Croatia & K. Vrandečić & НМ347702 & НМ347670 \\
\hline D. stewartii & CBS 193.36 & Cosmos bipinnatus & $\mathrm{n} / \mathrm{a}^{\mathrm{z}}$ & A.L. Harrison & FJ889448 & GQ250324 \\
\hline D. vaccinii & CBS 160.32 & Oxycoccus macrocarpus & Oregon, USA & H.F. Bain & AY952141 & GQ250326 \\
\hline D. viticola & CBS 113201 & V. vinifera & Portugal & A.J.L. Phillips & AY485750 & GQ250327 \\
\hline P. amygdali & $11 \mathrm{~A}$ & Prunus dulcis & Portugal & E. Diogo & GQ281792 & GQ250339 \\
\hline P. cuppatea & CBS 117499 & A. linearis & South Africa & J.C.J. van Rensburg & AY339322 & AY339354 \\
\hline P. dauci & CBS 315.49 & Daucus carota & Netherlands & J.A. von Arx & FJ889451 & GQ250348 \\
\hline P. phoenicicola & CBS 161.64 & Areca catechu & India & H.C. Srivastava & FJ889452 & GQ250349 \\
\hline P. sclerotioides & CBS 296.67 & Cucumis sativus & Netherlands & Van der Kesteren & AF439626 & GQ250350 \\
\hline P. viticola & CBS 114016 & V. vinifera & France & P. Larignon & AF230751 & GQ250351 \\
\hline P. viticola & 114 & $V$. vinifera & Portugal & E. Diogo & GQ250214 & GQ250352 \\
\hline P. viticola & 115 & $V$. vinifera & Portugal & E. Diogo & GQ250215 & GQ250353 \\
\hline P. viticola & Pho16 & $V$. vinifera & Massachusetts, USA & P. Rolshausen & JN214575 & JN192169 \\
\hline P. viticola & Pho25 & $V$. vinifera & Virginia, USA & P. Rolshausen & JN214584 & JN192178 \\
\hline P. viticola & PhoCT1L & $V$. vinifera & Connecticut, USA & P. Rolshausen & JN214592 & JN192186 \\
\hline P. viticola & UCD2236MO & $V$. vinifera & Missouri, USA & K. Striegler \& G.M. Leavitt & HQ288245 & HQ288280 \\
\hline P. viticola & UCD2599MO & $V$. vinifera & Missouri, USA & K. Striegler \& W.D. Gubler & HQ288248 & HQ288283 \\
\hline P. viticola & UCD2600MO & $V$. vinifera & Missouri, USA & K. Striegler \& W.D. Gubler & HQ288249 & HQ288284 \\
\hline P. viticola & UCD2317AR & $V$. vinifera & Arkansas, USA & K. Striegler \& G.M. Leavitt & HQ288247 & HQ288282 \\
\hline P. viticola & UCD2403TX & $V$. vinifera & Texas, USA & P. Adams & FJ790864 & GU294711 \\
\hline P. viticola & UCD2408TX & $V$. vinifera & Texas, USA & P. Adams & FJ790865 & KF017906 \\
\hline P. viticola & UCD2471TX & $V$. vinifera & Texas, USA & P. Adams & FJ790866 & KF017907 \\
\hline
\end{tabular}

${ }^{v}$ GenBank accession numbers in italics were generated in this study.

${ }^{w}$ Isolate numbers in bold represent ex-type specimens. CBS: Centraalbureau voor Schimmelcultures, Utrecht, Netherlands.

${ }^{x}$ ITS: internal transcribed spacer.

y EF1- $\alpha$ : Translation elongation factor $1-\alpha$.

${ }^{\mathrm{z}} \mathrm{n} / \mathrm{a}$ : not available. 
son Seedless (head trained and cane pruned) located at the University of California Field Station in Davis. All cultivars were prepruned to 8- to 10-bud short canes in December 2009, and fresh pruning wounds were immediately inoculated by applying $50 \mu \mathrm{l}$ of a $1 \times 10^{5}$ conidia/ml suspension from each isolate as previously described. Control treatments were inoculated by applying $50 \mu \mathrm{l}$ of sterile distilled water. Each treatment was applied onto one 1-yearold dormant cane per grapevine on each of 10 grapevines in a completely randomized design. Canes were collected 6 months after inoculation and brought to the laboratory. Length of vascular discoloration was measured and fulfillment of Koch's postulates was conducted as previously described.

Data analyses. Data from the different assays were independently analyzed using analysis of variance (ANOVA) in SAS (Version 9.2; SAS Institute, Cary, NC). For each experiment, homogeneity of variance was tested using Levene's test, residuals were visually inspected, and when necessary the $\log _{10}$ transformation was used to reduce heteroscedasticity. Within each of the three assays, the significance of the difference in length of discoloration caused by each treatment was determined by one-way ANOVA. Tukey's test at the 5\% significance level was used to analyze differences in the extent of vascular discoloration between the treatment means. A two-way ANOVA was performed to determine significant differences between Syrah and Red Globe grape cultivars in the cordon pathogenicity test. Length of vascular discoloration caused by both E. lata and Botryosphaeriaceae spp. in the mature wood cordon trial and Botryosphaeriaceae spp. in the Syrah dormant cane inoculation trial, previously published (58), were also included in the statistical analyses and compared against P. viticola.

\section{Results}

Morphological characterization. Based on colony and morphological characteristics of the conidia, the isolates selected in this study were classified into four different groups. The first group, which included the highest number of isolates, was characterized by white to light brown mycelium, becoming dark brown with age (Fig. 2a). Mycelium was slightly raised and slow growing, taking up to 4 weeks to reach 6-cm colony diameter on PDA. The colony of this type of isolate was characterized by forming prominent growth rings with margins becoming black with age (Fig. 2b and c). Colonies produced dark brown, eustromatic pycnidia from which mucilaginous light-cream cirrhi containing both alpha (hyaline, ellipsoidal, and unicellular) and beta (hyaline, filiform, and slightly curved) conidia were observed (Fig. 2b). These morphological characteristics were similar to previous descriptions of $P$. viticola $(9,22,30,39,57,60)$. A second group of isolates was characterized by white, dense, slightly aerial, fastgrowing mycelium (Fig. 2d). With age, sparse, solid-olivaceous dark patches of mycelium could be observed (Fig. 2e). Colonies became dark cream-colored in the central part and dark olivaceous toward the edge (Fig. 2f). Pycnidia were formed on PDA from which cream conidial masses containing hyaline, ellipsoidal, and biguttulate alpha-conidia were observed (Fig. 2g). Filiform betaconidia were not observed. The morphological characters of both colony and conidia were in agreement with those described by van Rensburg et al. (62) for Diaporthe ambigua Nitschke, and thus they were first tentatively classified as $D$. ambigua. The third group of isolates was characterized by having completely white, slowgrowing mycelium on both the surface and the reverse side (Fig. $2 \mathrm{~h}$ ). With age, the center of the colony became dark green, and black pycnidia covered in mycelium developed. Both alphaconidia (hyaline, fusoid, unicellular, and biguttulate) and betaconidia (hyaline, filiform, and aseptate) could be observed in the light cream-colored conidial masses exuded from the pycnidia. The last group of isolates was characterized by having a flat, white, and slow-growing mycelium, which developed forming prominent growth rings. With age, black flask-shaped pycnidia developed from which mucilaginous light cream-colored conidial masses exuded containing both alpha (hyaline, fusoid, biguttulate, and unicellular) and beta (hyaline, filiform, aseptate, and curved) conidia (Fig. 2i). Based on these morphological characters, it was not possible to identify isolates from groups three and four to species level, and they were first classified as Phomopsis sp. Identification to species level was achieved by ITS and EF1- $\alpha$ sequence analysis.

ITS and EF1- $\alpha$ phylogeny. PCR amplifications of the ITS and EF1- $\alpha$ selected regions gave products of approximately 0.5 and 0.3 $\mathrm{kb}$, respectively. To evaluate the phylogenetic relationships among the different Phomopsis/Diaporthe isolates obtained from grapevines in California, homologous sequence searches of the obtained ITS and EF1- $\alpha$ sequence data were performed using the BLAST program against the GenBank database. This allowed us to (i) confirm the preliminary morphological identification of $P$. viticola and D. ambigua; (ii) identify unidentified isolates from morphological groups 3 and 4 to species level; and (iii) select homologous sequences for the multi-locus phylogenetic analyses (Table 2). A total of 65 taxa were included in the phylogenetic analysis of the combined ITS and EF1- $\alpha$ dataset using Maximum Parsimony (MP) and Neighbor-Joining (NJ). The alignment contained a total of 886 characters including gaps. The MP evolutionary history generated 66 equally parsimonious trees, of which one is shown (Fig. 3). The $\mathrm{NJ}$ analysis resulted in a tree with similar topology as the MP tree. Based on the phylogenetic analysis of the combined ITS and EF1$\alpha$ dataset, Phomopsis/Diaporthe isolates originating from grapevines in California formed four well-supported clades confirming the morphological classification. The first clade, with bootstrap values of $100 \%$ (MP and NJ) and containing isolates from morphological group 1 , consists of $P$. viticola. $P$. viticola isolates from California, isolated from both perennial cankers and Phomopsis cane and leaf spot symptoms, had nearly identical sequences and grouped together with $P$. viticola isolates from grapevines from Arkansas, Connecticut, Massachusetts, Missouri, Texas, and Virginia in the United States, and Portugal and France, including the ex-type specimen CBS114016 (Fig. 3). The second clade, with bootstrap values of $100 \%$ (MP and $\mathrm{NJ}$ ) and containing isolates

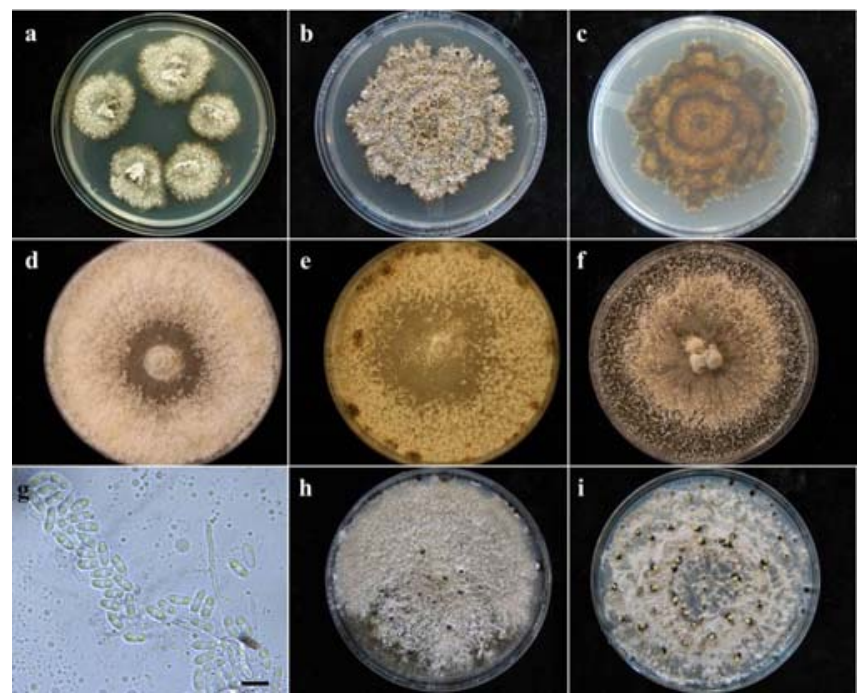

Fig. 2. Colony morphology of Phomopsis/Diaporthe species identified from grapevine cankers in California. a to c, Phomopsis viticola isolate UCCE989A. a, $P$. viticola was the sole fungus isolated from most of the grapevine perennial cankers collected in the San Joaquin Valley. b, Four-week-old light brown to gray $P$. viticola colony. Dark brown, eustromatic pycnidia with mucilaginous light cream-colored cirrhi-containing spores. c, Characteristic growth rings with margins becoming black with age could be observed on the back of the plate. $\mathbf{d}$ to $\mathbf{g}$, Diaporthe ambigua isolate UCD2076Te. d, Young colony characterized by white fluffy mycelium. e, Sparse, solid-olivaceous, dark patches of mycelium developed with age. f, Colonies became dark cream in the central part and dark olivaceous towards the margins. g, Diaporthe ambigua hyaline, ellipsoidal and biguttulate alpha-conidia. Scale bar $=10 \mu \mathrm{m} \mathrm{h}$, Diaporthe neotheicola isolate UCCE993B. i, Diaporthe eres isolate UCCE993A showing pycnidia with a mucilaginous light-cream cirrhi containing spores. 
from morphological group 3, consists of Diaporthe neotheicola A.J.L. Phillips \& J.M. Santos (Fig. 3). D. neotheicola isolates from California, isolated from perennial cankers, grouped together with D. neotheicola isolates from fennel (Foeniculum vulgare L.) from

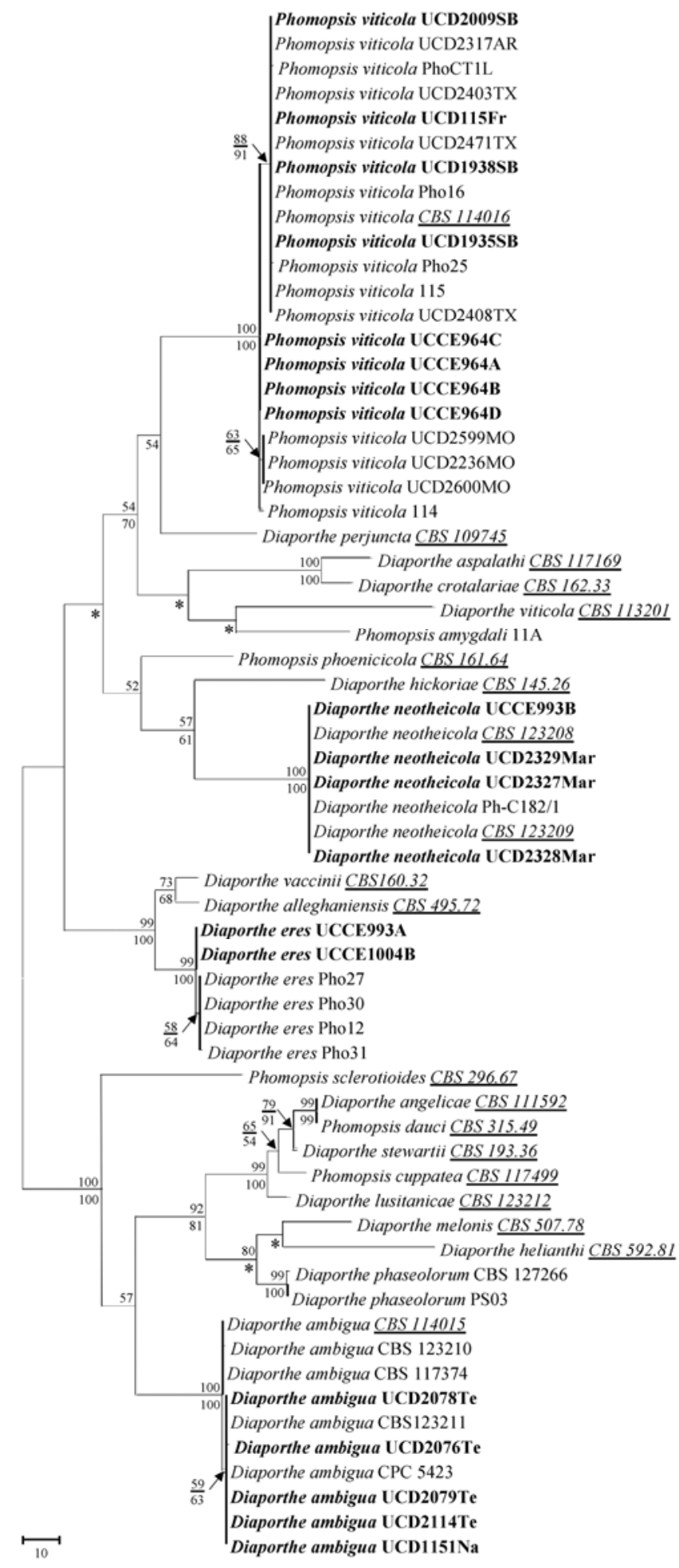

Fig. 3. One of 66 equally parsimonious trees resulting from the alignment of 886 characters of the combined ITS rDNA and EF1-a regions. Length $=697$; consistency index $(\mathrm{Cl})=0.497$, retention index $(\mathrm{RI})=0.887$, retention composite index $(\mathrm{RC})=0.470$. Isolates in bold represent Phompsis/Diaporthe isolated from grapevines in California in this study. Isolates in italics and underlined signify holotype cultures linked morphologically to the type material. Bootstrap values with 1,000 replications are shown above branches for maximum Parsimony (MP) (only bootstrap value higher than $50 \%$ is represented) and below the branches for neighborjoining (NJ). NJ optimal branch length sum $=0.992$. Branches represented with an asterisk were not present in the $\mathrm{NJ}$ tree. Bar represents 10 changes.
Portugal, including the ex-type specimen (Fig. 3). The third clade, with bootstrap values of $99 \%$ (MP) and $100 \%$ (NJ) and containing isolates from morphological group 4, consists of Diaporthe eres Nitschke (Fig. 3). D. eres isolates from California, which could not be identified to species based on morphological characters, grouped together with $D$. eres isolates from grapevines in Connecticut and New York in the United States and Québec in Canada (Fig. 3). The fourth clade, with bootstrap values of $100 \%$ (MP and NJ) containing isolates from morphological group 2, consists of $D$. ambigua (Fig. 3). D. ambigua isolates from grapevines in California, isolated only from perennial cankers, grouped together with $D$. ambigua isolates from non-grapevine hosts in Portugal and South Africa, including the ex-type specimen (Fig. 3).

Pathogenicity studies. Mature wood cordon inoculations. The mean extent of vascular discoloration caused by $P$. viticola isolate UCD1935SB at 24 months after inoculation was 54.2 and $49.3 \mathrm{~mm}$ in Red Globe and Syrah, respectively (Table 3). A two-way ANOVA revealed no significant differences in the extent of vascular discoloration caused by $P$. viticola isolate UCD1935SB between Red Globe and Syrah $(\mathrm{F}=2.88, P=0.0921)$. Reisolation rates of isolate UCD1935SB were 80 and $90 \%$ from Red Globe and Syrah, respectively (Table 3). The mean length of vascular discoloration caused by $P$. viticola isolate UCD1935SB in mature wood in both cultivars did not differ statistically from the vascular discoloration caused by the well-documented grapevine canker fungal pathogens Neofusicoccum parvum (Pennycook \& Samuels) Crous, Slippers \& A.J.L. Phillips and E. lata (Table 3). Perennial cankers developed from the point of inoculation with $P$. viticola isolate UCD1935SB in both cultivars by 24 months after inoculation.

Syrah dormant cane inoculations. The mean extent of vascular discoloration caused by $P$. viticola isolates UCD1935SB, UCD1938SB, and UCD115Fr at 13 months after inoculation and reisolation rates are shown in Table 4 . The length of vascular discoloration caused by $P$. viticola ranged from 35.9 to $28.4 \mathrm{~mm}$ and did not differ statistically from that caused by isolates of Botryosphaeria dothidea (Moug. ex Fr.) Ces. \& De Not. (38.4 mm), Diplodia mutila (Fr.) Mont. (38.7 mm), Diplodia seriata De Not. (32.3 $\mathrm{mm}$ ), and E. lata (ranged from 49.5 to $39.9 \mathrm{~mm}$ ) from the same study (Table 4). Vascular discoloration and perennial wedge-shaped cankers had developed from the point of inoculation with the $P$. viticola isolates by 13 months after inoculation (Fig. If and g).

Grapevine cultivar susceptibility to infection by $\mathrm{P}$. viticola and Diaporthe spp. The mean extent of vascular discoloration caused by $P$. viticola isolates UCD115Fr, UCCE964A, and UCD1935SB; D. ambigua isolates UCD1151Na and UCD2079Te; and D. neotheicola isolate UCD2327Mar at 6 months after inoculation on cvs. Barbera, Cabernet Sauvignon, Chardonnay, Merlot, Thompson Seedless, and Zinfandel and their reisolation rates are shown in Table 5. Among all three species tested, P. viticola was the most virulent in all six cultivars, with reisolation rates always higher than $60 \%$. P. viticola isolates caused longer vascular discoloration than the water-inoculated controls in all six cultivars. Overall, statistical analyses revealed Zinfandel and Cabernet Sauvignon to be the cultivars most susceptible to $P$. viticola. Length of vascular discoloration caused by $P$. viticola did not differ statistically among cvs. Thompson Seedless, Barbera, Chardonnay, and Merlot. Overall, D. ambigua and D. neotheicola caused smaller lesions than $P$. viticola, which in some cases were not statistically different than the water-inoculated controls. Thompson Seedless and Cabernet Sauvignon were susceptible to infection by $D$. ambigua isolates UCD1151Na and UCD2079Te, respectively. D. ambigua reisolation rates ranged between 40 and $70 \%$. Among all three species studied, D. neotheicola showed the lowest reisolation rates (20 to $50 \%$ ) in all cultivars except Thompson Seedless, in which the fungus was reisolated from $80 \%$ of the inoculated canes (Table 5).

\section{Discussion}

Morphological studies along with sequence analyses of both the ITS and EF1- $\alpha$ regions confirmed the identification of $P$. viticola 
from grapevine cankers and Phomopsis cane and leaf spot symptoms in California, and also revealed the presence of D. ambigua, $D$. eres, and D. neotheicola from symptomatic grapevine wood. Although these three Diaporthe spp. have long been described as either pathogens or endophytes from different hosts (18), their occurrence on grapevines has only recently been reported $(4,64)$. While P. viticola has long been known to occur in California vineyards (21), this is, to our knowledge, the first report of D. ambigua, $D$. eres, and D. neotheicola on grapevines in the state of California.

Species identification in Phomopsis/Diaporthe had historically been based on morphological and cultural characteristics, as well as on host affiliation $(30,35,43,47,54,55)$. These species recognition criteria have long been used on grapevines to identify $P$. viticola, which for many years was the sole Phomopsis species reported to occur in this host. However, it is currently wellaccepted that the vast majority of the Phomopsis/Diaporthe spp. can only be properly identified to species by using DNA sequence analyses $(8,12,46,47,53,54)$. Nevertheless, solely using ITS analysis was not sufficient to separate all Phomopsis/Diaporthe isolates from California (single ITS phylogenetic tree not shown). Isolate classification was only possible when either the single EF1$\alpha$ or combined ITS and EF1- $\alpha$ phylogenies were analyzed. These results are in agreement with the recent suggestion that EF1- $\alpha$ is a better phylogenetic marker in Diaporthe and Phomopsis than ITS (46). Although Castlebury et al. (8) previously reported the ITS region not to be particularly informative in Phomopsis, most of the molecular approaches to identify Phomopsis/Diaporthe spp. over the last decade have relied only on ITS sequences, since they are the most common in databases $(8,12,24,47,57,61,64)$. More recently, several studies have shown multi-locus phylogenetic analyses to provide better resolution for Phomopsis/Diaporthe spp. than single-gene analyses, and sequences from up to six different loci including ITS, EF1- $\alpha, \beta$-tubulin, calmodulin, and mating types (MAT1-1-1 and MAT1-2-1) are currently available in GenBank $(46,47,53,54,62)$.

P. viticola has been long known and studied as a pathogen of grapevines, and pathogenicity studies conducted in the early $1900 \mathrm{~s}$ and mid-1960s suggested that this fungus was able to infect mature wood and cause perennial cankers $(9,10,42)$. However, all these studies failed in the attempt to reproduce the dead-arm stunted and chlorotic spring growth foliar symptoms thought to be associated with $P$. viticola. Due to these inconclusive results, and after a decade of studies focused on E. lata as the sole causal agent of grapevine dieback $(14,25,27,28)$, Moller and Kasimatis (29) concluded in the early 1980 s that grapevine cankers and consequent dead-arm symptoms were caused solely by E. lata and not $P$. viticola. Consequently, the majority of the studies over the past 30 years have only focused on studying $P$. viticola as the causal agent of Phomopsis cane and leaf spot $(1,16,17,31-34,36-38,48)$, and pathogenicity studies of $P$. viticola and other Phomopsis/Diaporthe spp. only involved testing on green grapevine tissues $(30,31,36,40,48,62)$.
Therefore, this study represents the first attempt over the past 40 years to re-evaluate the role of $P$. viticola as a grapevine cankercausing agent, as well as to determine susceptibility of different grapevine cultivars to wood infection caused by $P$. viticola and other Diaporthe spp. found in grapevines in California.

Results from the grapevine cordon inoculation trial show that $P$. viticola isolates from California can successfully infect and colonize mature grapevine wood and develop perennial cankers beyond the point of inoculation, which confirm the original observations and results reported by Reddick $(41,42)$, Coleman (10), and Chamberlain et al. (9); but are in disagreement with those reported by Moller and Kasimatis (29). Although the lengths of discoloration recorded in the cordon inoculation trial were substantially smaller than those reported by both Reddick (42) and Coleman (10), reisolation success of $P$. viticola from the cankers developed in the inoculated cordons in this study was much higher than those previously reported $(10,29,42)$. These differences could be a consequence of several factors; however, variability in isolate virulence, mode and time of inoculation, and differences in grapevine cultivar susceptibility have all been shown to play an important role in differences observed among other grapevine trunk pathogens $(52,58)$. Therefore, the use of a nonvirulent isolate could be one of the reasons why the P. viticola isolate used by Moller and Kasimatis (29) did not cause symptoms when inoculated into mature wood. Results

Table 4. Mean lesion length caused by Phomopsis viticola isolates UCD1935SB, UCD1938SB, UCD115Fr and comparison against other fungal grapevine trunk pathogens on Syrah dormant canes 13 months after inoculation

\begin{tabular}{|c|c|c|c|}
\hline Species & Isolate & Lesion length $^{\mathrm{x}} \pm \mathrm{SE}$ & $\mathbf{R}^{\mathbf{y}}$ \\
\hline Neofusicoccum parvum ${ }^{\mathrm{z}}$ & UCD642So & $105.6 \pm 19.6 \mathrm{a}$ & 10 \\
\hline Lasiodiplodia theobromae ${ }^{\mathrm{z}}$ & UCD1814Md & $92.5 \pm 14.9 \mathrm{a}$ & 10 \\
\hline Botryosphaeria dothidea $^{\mathrm{z}}$ & UCD1065So & $58.8 \pm 14.8 \mathrm{~b}$ & 10 \\
\hline Eutypa lata & DHB100 & $49.5 \pm 10.9 b c$ & 9 \\
\hline E. lata & DCA200 & $40.2 \pm 9.6 \mathrm{bc}$ & 8 \\
\hline E. lata & UCD782St & $39.9 \pm 5.5 \mathrm{bc}$ & 9 \\
\hline Diplodia mutilaz & UCD1953SB & $38.7 \pm 5.8 \mathrm{bc}$ & 7 \\
\hline B. dothidea ${ }^{\mathrm{z}}$ & UCD1181Me & $38.4 \pm 8.1 \mathrm{bc}$ & 10 \\
\hline Phomopsis viticola & UCD115Fr & $35.9 \pm 3.6 \mathrm{bc}$ & 9 \\
\hline Dothiorella viticola ${ }^{\mathrm{z}}$ & UCD1642Yo & $33.6 \pm 4.9 \mathrm{bc}$ & 7 \\
\hline P. viticola & UCD1938SB & $32.7 \pm 3.3 \mathrm{bc}$ & 8 \\
\hline Diplodia seriata ${ }^{\mathrm{Z}}$ & UCD244Ma & $32.3 \pm 7.2 \mathrm{c}$ & 10 \\
\hline P. viticola & UCD1935SB & $28.4 \pm 2.9 \mathrm{c}$ & 6 \\
\hline $\mathrm{Control}^{\mathrm{z}}$ & & $13.4 \pm 1.2 \mathrm{~d}$ & 0 \\
\hline
\end{tabular}

${ }^{x}$ Mean lesion length in millimeters. Mean values correspond to the extent of vascular discoloration measured downward from the point of inoculation. SE: Standard error of the mean. Means with the same letter are not significantly different at the 0.05 level according to Tukey's test.

y R: Number of samples from which the fungus was reisolated out of 10 samples inoculated.

${ }^{\mathrm{z}}$ Botryosphaeriaceae spp. results obtained in the same trial and published in 2009 (58) are included in the table for comparison against $P$. viticola.

Table 3. Comparison of mean lesion length caused by Phomopsis viticola isolate UCD1935SB and other fungal grapevine trunk pathogens on cordons of 'Red Globe' and 'Syrah' 24 months after inoculation

\begin{tabular}{|c|c|c|c|c|c|}
\hline \multirow[b]{2}{*}{ Species } & \multirow[b]{2}{*}{ Isolate } & \multicolumn{2}{|l|}{ Red Globe } & \multicolumn{2}{|l|}{ Syrah } \\
\hline & & Lesion length $(\mathrm{mm})^{x} \pm S E$ & $\mathbf{R}^{\mathbf{y}}$ & Lesion length $(\mathrm{mm})^{x} \pm \mathrm{SE}$ & $\mathbf{R}^{\mathbf{y}}$ \\
\hline Lasiodiplodia theobromae ${ }^{\mathrm{z}}$ & UCD1814Md & $80.2 \pm 5.6 \mathrm{a}$ & 10 & $80.4 \pm 6.7 \mathrm{a}$ & 10 \\
\hline Neofusicoccum parvum ${ }^{z}$ & UCD642So & $75.1 \pm 9.7 \mathrm{ab}$ & 10 & $63.8 \pm 5.2 \mathrm{~b}$ & 10 \\
\hline Eutypa lata & DHB100 & $70.8 \pm 8.1 \mathrm{ab}$ & 8 & $60.1 \pm 3.2 \mathrm{~b}$ & 7 \\
\hline Phomopsis viticola & UCD1935SB & $54.2 \pm 6.8 \mathrm{bc}$ & 8 & $49.5 \pm 4.3 \mathrm{bc}$ & 9 \\
\hline Botryosphaeria dothidea ${ }^{\mathrm{Z}}$ & UCD1181Me & $47.8 \pm 4.5 \mathrm{c}$ & 7 & $42.6 \pm 5.9 \mathrm{dc}$ & 7 \\
\hline Diplodia mutilaz & UCD1953SB & $33.1 \pm 2.5 \mathrm{dc}$ & 6 & $30.3 \pm 5.8 \mathrm{de}$ & 7 \\
\hline Control $^{\mathrm{Z}}$ & & $26 \pm 1.4 \mathrm{~d}$ & 0 & $21.3 \pm 1.2 \mathrm{e}$ & 0 \\
\hline
\end{tabular}

${ }^{\mathrm{x}}$ Mean lesion length in millimeters. Values correspond to the mean of the sum of both upward and downward extent of vascular discoloration measured from the point of inoculation. SE: Standard error of the mean. Means with the same letter are not significantly different at the 0.05 level according to Tukey's test.

${ }^{y} \mathrm{R}$ : Number of samples from which the fungus was re-isolated out of 10 samples inoculated.

${ }^{\mathrm{z}}$ Eutypa lata and Botryosphaeriaceae spp. results obtained in the same trial and published in 2009 (58) are included in the table for comparison against P. viticola. 
Table 5. Mean lesion length caused by Phomopsis viticola and Diaporthe species in six different Vitis vinifera cultivars

\begin{tabular}{|c|c|c|c|c|c|c|c|c|c|c|c|c|c|}
\hline \multirow[b]{3}{*}{ Cultivar } & \multirow[b]{3}{*}{ Control } & \multicolumn{6}{|c|}{ Phomopsis viticola } & \multicolumn{4}{|c|}{ Diaporthe ambigua } & \multirow{2}{*}{\multicolumn{2}{|c|}{$\begin{array}{c}\text { Diaporthe neotheicola } \\
\text { UCD2327Mar }\end{array}$}} \\
\hline & & \multicolumn{2}{|c|}{ UCD115Fr } & \multicolumn{2}{|c|}{ UCCE964A } & \multicolumn{2}{|c|}{ UCD1935SB } & \multicolumn{2}{|c|}{ UCD1151Na } & \multicolumn{2}{|c|}{ UCD2079Te } & & \\
\hline & & $(\mathbf{m m})^{\mathrm{u}} \pm \mathrm{SE}^{\mathrm{v}}$ & $\mathbf{R}^{\mathbf{w}}$ & $(\mathbf{m m})^{\mathbf{u}} \pm \mathrm{SE}^{\mathrm{v}}$ & $\mathbf{R}^{\mathbf{w}}$ & $(\mathbf{m m})^{\mathbf{u}} \pm \mathrm{SE}^{\mathbf{v}}$ & $\mathbf{R}^{\mathbf{w}}$ & $(\mathbf{m m})^{\mathrm{u}} \pm \mathrm{SE}^{\mathrm{v}}$ & $\mathbf{R}^{\mathbf{w}}$ & $(\mathbf{m m})^{\mathrm{u}} \pm \mathrm{SE}^{\mathrm{v}}$ & $\mathbf{R}^{\mathbf{w}}$ & $(\mathbf{m m})^{\mathrm{u}} \pm \mathrm{SE}^{\mathrm{v}}$ & $\mathbf{R}^{\mathbf{w}}$ \\
\hline Zinfandel & $4.1 \pm 0.4$ & $42.7 \pm 4.7 \mathrm{a}^{\mathrm{x}}$ & 6 & $28.6 \pm 2.6 \mathrm{a}^{\mathrm{x}}$ & 9 & $21.7 \pm 1.6 b^{x}$ & 8 & $8.8 \pm 0.5 b$ & 4 & $12.7 \pm 4.7 b$ & 6 & $8 \pm 0.8 b$ & 3 \\
\hline Cabernet $^{\mathrm{y}}$ & $3.6 \pm 0.3$ & $31.9 \pm 2.4 \mathrm{~b}^{\mathrm{x}}$ & 10 & $28.8 \pm 1.4 \mathrm{a}^{\mathrm{x}}$ & 10 & $30.7 \pm 1.5 \mathrm{a}^{\mathrm{x}}$ & 8 & $9.3 \pm 1.2 b^{x}$ & 6 & $16.8 \pm 1.8 \mathrm{a}^{\mathrm{x}}$ & 7 & $13.2 \pm 1.1 \mathrm{a}^{\mathrm{x}}$ & 4 \\
\hline Thompson $^{\mathrm{z}}$ & $2.9 \pm 0.3$ & $19.7 \pm 2.3 c^{x}$ & 7 & $15.3 \pm 1.6 b^{x}$ & 8 & $14.4 \pm 1.5 c^{\mathrm{x}}$ & 7 & $17.3 \pm 3.6 \mathrm{a}^{\mathrm{x}}$ & 6 & $10.2 \pm 0.9 b^{x}$ & 7 & $14.1 \pm 2.7 \mathrm{a}^{\mathrm{x}}$ & 8 \\
\hline Barbera & $3.4 \pm 0.4$ & $15.8 \pm 1.9 \mathrm{c}^{\mathrm{x}}$ & 7 & $15.8 \pm 1.6 b^{x}$ & 8 & $16.9 \pm 1.2 b c^{x}$ & 8 & $9.5 \pm 1.1 b^{x}$ & 6 & $7.2 \pm 0.6 b^{x}$ & 3 & $6.8 \pm 0.6 b$ & 2 \\
\hline Chardonnay & $3.8 \pm 0.5$ & $11.9 \pm 1.2 \mathrm{c}^{\mathrm{x}}$ & 7 & $13.8 \pm 1.9 \mathrm{~b}^{\mathrm{x}}$ & 10 & $17.5 \pm 1.6 b^{x}$ & 10 & $11.3 \pm 0.8 b^{x}$ & 4 & $9.3 \pm 0.7 b^{x}$ & 6 & $10.8 \pm 1.3 \mathrm{ab}^{\mathrm{x}}$ & 5 \\
\hline Merlot & $3.8 \pm 0.4$ & $13.2 \pm 1.2 \mathrm{c}^{\mathrm{x}}$ & 10 & $14.5 \pm 1.3 b^{x}$ & 10 & $15.5 \pm 2.6 \mathrm{c}^{\mathrm{x}}$ & 10 & $8.8 \pm 0.9 b^{x}$ & 5 & $7.5 \pm 0.5 b$ & 4 & $7.6 \pm 0.8 \mathrm{~b}$ & 3 \\
\hline Average & $3.6 \pm 0.4$ & $22.5 \pm 2.3$ & 7.8 & $19.5 \pm 1.7$ & 9.3 & $19.4 \pm 1.6$ & 8.5 & $10.8 \pm 1.4$ & 5.1 & $10.6 \pm 1.6$ & 5.5 & $10.1 \pm 1.2$ & 4.1 \\
\hline
\end{tabular}

" Mean lesion length in millimeters. Mean values correspond to the extent of vascular discoloration measured downward from the point of inoculation.

v SE: Standard error of the mean. Means within columns with the same letter are not significantly different at the 0.05 level according to Tukey's test.

${ }^{\mathrm{w}} \mathrm{R}$ : Number of samples from which the fungus was reisolated out of 10 samples inoculated.

${ }^{x}$ Significant differences at the 0.05 level based on a Tukey's test between the vascular discolorations means of each treatment and control plants per row.

y Cabernet Sauvignon.

$\mathrm{z}$ Thompson Seedless.

obtained in the current study from the Syrah dormant cane inoculation trial showed all three different $P$. viticola isolates from California to be pathogenic and to cause longer discoloration than the noninoculated controls. Overall, these results support recent pathogenicity tests performed under controlled environmental conditions (mycelia and/or spore inoculation of dormant potted vines in greenhouse tests) in which $P$. viticola isolates from different grapegrowing regions and isolated from perennial cankers from declining vines were shown to cause noticeable vascular discolorations in woody tissue $(4,57,60)$. Additionally, the latter pathogenicity tests showed no differences in susceptibility of dormant grapevine wood to infection caused by $P$. viticola between $V$. vinifera 'Cabernet Sauvignon' and 'Red Globe' (57), among four different interspecific hybrids (60), and between $V$. labruscana 'Concord' and $V$. vinifera 'Chardonnay' (4). Similarly, this study revealed no statistical differences in susceptibility caused by $P$. viticola between Syrah and Red Globe when mature wood was inoculated. In California, the cultivar Thompson Seedless has been historically known as highly susceptible to Phomopsis cane and leaf spot $(19,26)$. However, there is very little information regarding the susceptibility of pruning wounds to $P$. viticola infection. Interestingly, Thompson Seedless dormant wood was shown in this study to be not highly susceptible to infection caused by $P$. viticola. Although most of the $P$. viticola isolates obtained from perennial cankers in the San Joaquin Valley were isolated from Thompson Seedless (J. R. Úrbez-Torres, unpublished data), these results may indicate $P$. viticola to be more successful infecting grape tissues such as leaves, green shoots, rachis, and berries, all associated with Phomopsis cane and leaf spot, than dormant wood in specific cultivars.

This study reported for the first time the occurrence of $D$. ambigua, D. eres, and D. neotheicola on grapevines in California. Previous pathogenicity studies conducted in vitro on green shoots showed D. ambigua to cause lesions similar to the nonpathogen Clonostachys rosea (Link) Schroers, Samuels, Seifert \& W. Gams and the noninoculated controls (61). Although the anamorph of $D$. neotheicola, Phomopsis theicola Curzi, was reported from escainfected grapevines in South Africa, no pathogenicity studies were conducted (64). Consequently, with the current information available and until further pathogenicity studies are completed, D. ambigua and D. neotheicola are suggested here as saprophytes on grapevine wood. In this study, D. eres was isolated and identified after conclusion of the pathogenicity studies. Thus, it could not be included in any of the trials. D. eres was recently found associated with grapevine perennial cankers in vineyards in the northeastern United States, and preliminary pathogenicity studies suggested that this species is pathogenic on grapevines but less virulent than $P$. viticola (4).

When P. viticola was originally described as the causal agent of the dead-arm disease, it was also thought to be responsible for the foliar symptomatology observed in the declining vines, which included lack of spring growth, bud mortality, shoot dieback, short shoot internodes, small leaves crimped about the margin, and fruit shriveling (41). However, research conducted since the mid-1970s has clearly shown that symptoms such as shoot dieback, short shoot internodes, and crimping of the leaves are indeed caused by the fungal pathogen E. lata $(7,28,29,50)$. In the current study, none of these symptoms were observed in any of the pathogenicity trials conducted, further supporting that $E$. lata and not $P$. viticola is responsible for this symptomatology. On the other hand, lack of spring growth and subsequent bud mortality, originally thought to be caused by $P$. viticola but currently associated primarily with Botryosphaeria dieback (56), were recorded in both the Syrah dormant canes and the cultivar susceptibility trials. These results not only support the observations made in the early 1900s $(10,41,42)$, but also those from field surveys recently conducted in different grape-growing areas in the United States, in which $P$. viticola was isolated alone from grapevine cankers from declining vines showing lack of spring growth and bud mortality $(57,59,60)$.

This study has shown $P$. viticola isolates from California to be pathogenic on mature wood and to cause perennial cankers and vascular discoloration similar to those caused by E. lata and several Botryosphaeriaceae spp., which strongly support the role of $P$. viticola as a grapevine wood pathogen and suggest its addition among the fungi involved in the grapevine trunk disease complex. Future research should focus on investigating the time of pruning wound infection in the different grape-growing regions, in order to develop control strategies that may differ from those currently used to prevent Phomopsis cane and leaf spot.

\section{Acknowledgments}

This research was possible thanks to partial funding from the American Vineyard Foundation and the Viticulture Consortium West.

\section{Literature Cited}

1. Anco, D. J., Madden, L. V., and Ellis, M. A. 2012. Temporal patterns of sporulation potential of Phomopsis viticola on infected grape shoots, canes, and rachises. Plant Dis. 96:1297-1302.

2. Anderson, H. W., and Colby, A. S. 1943. Dead-arm disease of grape in Illinois. Plant Dis. Rep. 27:245-246.

3. Barnes, E. H. 1963. Incidence of systemic dead-arm and its relation to topography in Michigan vineyards. Plant Dis. Rep. 47:872-874.

4. Baumgartner, K., Fujiyoshi, P. T., Travadon, R., Castlebury, L. A., and Rolshausen, P. E. 2012. Characterization of Phomopsis species recovered from wood cankers in eastern North American vineyards. (Abstr.) Phytopathol Mediterr. 51:420.

5. Braun, A. J. 1961. Dead-arm, a disease of grapes. Farm Res. 27:7.

6. Carbone, I., Anderson, J. B., and Kohn, L. M. 1999. A method for designing primer sets for the speciation studies in filamentous ascomycetes. Mycologia 91:553-556

7. Carter, M. V. 1991. The status of Eutypa lata as a pathogen. Phytopathological Paper No. 32, International Mycological Institute, CAB International, Surrey, UK,

8. Castlebury, L. A., Farr, D. F., and Rossman, A. Y. 2001. Phylogenetic distinction of Phomopsis isolates from cucurbits. Inoculum 52:25.

9. Chamberlain, G. C., Willison, R. S., Townshend, J. L., and de Ronde, J. H 1964. Two fungi associated with the dead-arm disease of grape. Can. J. Bot. 42:351-355.

10. Coleman, L. C. 1928. The dead-arm disease of grapes in Ontario. A prelimi- 
nary study. Scientific Agric. 8:281-315.

11. Cucuzza, J. D., and Sall, M. A. 1982. Phomopsis cane and leaf spot of grapevines: Effects of chemical treatments on inoculum level, disease severity and yield. Plant Dis. 66:794-797.

12. Diogo, E. L. F., Santos, J. M., and Phillips, A. J. L. 2010. Phylogeny, morphology and pathogenicity of Diaporthe and Phomopsis species on almond in Portugal. Fungal Divers. 44:107-115.

13. Du Plessis, S. J. 1938. The occurrence of the dead-arm disease of vines in South Africa. Union of South Africa Department of Agriculture and Forestry Sciences Bull. 175:1-9.

14. Dye, M. H., and Carter, M. V. 1976. Association of Eutypa armeniacae and Phomopsis viticola with a dieback disease of grapevines in New Zealand. Australian Plant Pathology Society Newsl. 5:6-7.

15. Ellis, M. A., Welty, C., Funt, R. C., Doohan, D., and Williams, R. N., eds. 2004. Midwest small fruit pest management handbook. Ohio State University Extension, Columbus, OH.

16. Erincik, O., Madden, L. V., Ferree, D. C., and Ellis, M. A. 2001. Effect of growth stage on susceptibility of grape berry and rachis tissues to infection by Phomopsis viticola. Plant Dis. 85:517-520.

17. Erincik, O., Madden, L. V., Ferree, D. C., and Ellis, M. A. 2003. Temperature and wetness-duration requirements for grape leaf and cane infection by Phomopsis viticola. Plant Dis. 87:832-840.

18. Farr, D. F., and Rossman, A. Y. 2012. Fungal Databases, Systematic Mycology and Microbiology Laboratory, ARS, USDA. Retrieved September 15, 2012 from: http://nt.ars-grin.gov/fungaldatabases/

19. Gubler, W., and Leavitt, G. 1992. Phomopsis cane and leaf spot. Pages 8588 in: Grape Pest Management, 2nd ed. University of California Division of Agriculture and Natural Resources Publ. 3343, Oakland, CA.

20. Hall, T. A. 1999. BioEdit: A user-friendly biological sequence alignment editor and analysis program for Windows 95/98/NT. Nucleic Acid S. 41:95-98.

21. Hewitt, W. B. 1935. Dead-arm disease of grapes in California. Plant Dis. Rep. 19:309-310.

22. Hewitt, W. B., and Pearson, R. C. 1988. Phomopsis cane and leaf spot. Pages 17-18 in: Compendium of Grape Diseases. American Phytopathological Society, St. Paul, MN.

23. Hiura, M. 1924. On the Dead Arm of grapes in the vicinity of Sapporo. Sapporo Agriculture \& Forestry School Bull. 67.

24. Kajitani, Y., and Kanematsu, S. 2000. Diaporthe kyushuensis sp. nov., the leomorph of the causal fungus of grapevine swelling arm in Japan, and its anamorph Phomopsis vitimegaspora. Mycoscience 41:111-114.

25. Kouyeas, H., Chitzanidis, A., Pappas, A., and Carter, M. V. 1976. Eutypa armeniacae on apricot and grapevine in Greece. Phytopathology 87:260263.

26. Leavitt, G. 2000. Diseases. Pages 162-172 in: Raisin Production Manual. University of California Division of Agricultural and Natural Resources Publ. 3393, Oakland, CA.

27. Moller, W. J., Braun, A. J., Uyemoto, J. K., and Kasimatis, A. N. 1977. Eutypa armeniacae inoculum associated with dead arm-affected grapevines in New York and Ontario. Plant Dis. Rep. 61:422-423.

28. Moller, W. J., and Kasimatis, A. N. 1978. Dieback of grapevines caused by Eutypa armeniacae. Plant Dis. Rep. 62:254-258.

29. Moller, W. J., and Kasimatis, A. N. 1981. Further evidence that Eutypa armeniacae - not Phomopsis viticola - incites dead arm symptoms on grape. Plant Dis. 65:429-431.

30. Mostert, L., Crous, P. W., Kang, J. C., and Phillips, A. J. L. 2001. Species of Phomopsis and Libertella occurring on grapevines with specific references to South Africa: Morphological, cultural, molecular, and pathological characterization. Mycologia 93:146-167

31. Mostert, L., Crous, P. W., and Petrini, O. 2001. Endophytic fungi associated with shoots and leaves of Vitis vinifera, with specific reference to Phomopsis viticola complex. Sydowia 52:46-58.

32. Nita, M., Ellis, M. A., Wilson, L. L., and Madden, L. V. 2006. Effects of application of fungicide during the dormant period on Phomopsis cane and leaf spot of grape disease intensity and inoculum production. Plant Dis. 90:1195-1200.

33. Nita, M., Ellis, M. A., Wilson, L. L., and Madden, L. V. 2006. Evaluation of a disease warning system for Phomopsis cane and leaf spot of grape: A field study. Plant Dis. 90:1239-1246.

34. Phillips, A. J. L. 1998. Botryosphaeria dothidea and other fungi associated with excoriose and dieback of grapevines in Portugal. J. Phytopathol. 146:327-332.

35. Phillips, A. J. L. 1999. The relationship between Diaporthe perjuncta and Phomopsis viticola on grapevines. Mycologia 91:1001-1007.

36. Phillips, A. J. L. 2000. Excoriose, cane blight and related diseases of grapevines: A taxonomic review of the pathogen. Phytopathol. Mediterr. 39:341356.

37. Pscheidt, J. W., and Pearson, R. C. 1989. Time of infection and control of Phomopsis fruit rot of grape. Plant Dis. 73:829-833.

38. Pscheidt, J. W., and Pearson, R. C. 1989. Effect of grapevine training sys- tems and pruning practices on occurrence of Phomopsis cane and leaf spot. Plant Dis. 73:825-828.

39. Punithalingam, E. 1979. Phomopsis viticola. IMI Descriptions of Fungi and Bacteria 64, Sheet 635. Kew, Surrey, England.

40. Rawnsley, B., Wicks, T. J., Scott, E. S., and Stummer, B. E. 2004. Diaporthe perjuncta does not cause Phomopsis cane and leaf spot disease of grapevines in Australia. Plant Dis. 88:1005-1010.

41. Reddick, D. 1909. Necrosis of the grapevine. Cornell University Agriculture Experimental Station Bull. 263:323-343.

42. Reddick, D. 1914. Dead arm disease of grapes. New York State Agriculture Experimental Station, Geneva, NY. Bull. 389:463-490.

43. Rehner, S. A and Uecker, F. A. 1994. Nuclear ribosomal internal transcribed spacer phylogeny and host diversity in the coelomycete Phomopsis. Can. J. Bot. 72:1666-1674.

44. Robert, V., Stegehuis, G., and Stalpers, J. 2005. The MycoBank engine and related databases. Retrieved September 15, 2012, from http://www. mycobank.org

45. Saccardo, P. A. 1905. Notae mycologicae. Series V. Ann. Mycol. 3:165-171.

46. Santos, J. M., Correia, V. G., and Phillips, A. J. L. 2010. Primers for mating type diagnosis in Diaporthe and Phomopsis: Their use in teleomorph induction in vitro and biological species definition. Fungal Biol. 114:255-270.

47. Santos, J. M., and Phillips, A. J. L. 2009. Resolving the complex of $\mathrm{Di}$ aporthe (Phomopsis) species occurring on Foeniculum vulgare in Portugal. Fungal Divers. 34:109-123.

48. Schilder, A. M. C., Erincik, O., Castlebury, L. A., Rossman, A., and Ellis, M. A. 2005. Characterization of Phomopsis spp. infecting grapevines in the Great Lakes region of North America. Plant Dis. 89:755-762.

49. Shear, C. L. 1911. The ascogenous form of the fungus causing dead-arm of the grape. Phytopathology 1:116-119.

50. Sosnowski, M. R., Shtienberg, D., Creaser, M. L., Wicks, T. J., Lardner, R., and Scott, E. S. 2007. The influence of climate on foliar symptoms of Eutypa dieback in grapevines. Phytopathology 97:1284-1289.

51. Tamura, K., Peterson, D., Peterson, N., Stecher, G., Nei, M., and Kumar, S. 2011. MEGA5: Molecular Evolutionary Genetics Analysis using Maximum Likelihood, Evolutionary Distance, and Maximum Parsimony Methods. Mol. Biol. Evol. 28:2731-2739.

52. Trouillas, F. P., and Gubler, W. D. 2010. Pathogenicity of Diatrypaceae species in grapevines in California. Plant Dis. 94:867-872.

53. Udayanga, D., Xingzhong, L., Crous, P. W., McKenzie, E. H. C., Chukeatirote, E., and Hyde, K. D. 2012. A multi-locus phylogenetic evaluation of Diaporthe (Phomopsis). Fungal Divers. 56:157-171.

54. Udayanga, D., Xingzhong, L., McKenzie, E. H. C., Chukeatirote, E., Bahkali, A. H. A., and Hyde, K. D. 2011. The genus Phomopsis: Biology, applications, species concepts and names of common phytopathogens. Fungal Divers. 50:189-225.

55. Uecker, F. A. 1988. A world list of Phomopsis names with notes on nomenclature, morphology, and biology. Mycol. Memoir 13:1-213.

56. Úrbez-Torres, J. R. 2011. The status of Botryosphaeriaceae species infecting grapevines. Phytopathol. Mediterr. 50:S5-S45.

57. Úrbez-Torres, J. R., Adams, P., Kamas, J., and Gubler, W. D. 2009. Identification, incidence, and pathogenicity of fungal species associated with grapevine dieback in Texas. Am. J. Enol. Vitic. 60:497-507.

58. Úrbez-Torres, J. R., and Gubler, W. D. 2009. Pathogenicity of Botryosphaeriaceae species isolated from grapevine cankers in California. Plant Dis. 93:584-592.

59. Úrbez-Torres, J. R., Leavitt, G. M., Voegel, T. M., and Gubler, W. D. 2006. Identification and distribution of Botryosphaeria spp. associated with grapevine cankers in California. Plant Dis. 90:1490-1503.

60. Úrbez-Torres, J. R., Peduto, F., Striegler, R. K., Urrea-Romero, K. E., Rupe, J. C., Cartwright, R. D., and Gubler, W. D. 2012. Characterization of fungal pathogens associated with grapevine trunk diseases in Arkansas and Missouri. Fungal Divers. 52:169-189.

61. van Niekerk, J. M., Groenewald, J. Z., Farr, D. F., Fourie, P. H., Halleen, F., and Crous, P. W. 2005. Reassessment of Phomopsis species on grapevines. Australas. Plant Pathol. 34:27-39.

62. van Rensburg, J. C. J., Lamprecht, S. C., Groenewald, J. Z., Castlebury, L. A., and Crous, P. W. 2006. Characterisation of Phomopsis spp. associated with dieback of rooibos (Aspalathus linearis) in South Africa. Stud. Mycol. 55:65-74.

63. White, T. J., Bruns, T., Lee, S., and Taylor, J. 1990. Amplification and direct sequencing of fungal ribosomal RNA genes for phylogenetics. Pages 315322 in: PCR Protocols, A Guide to Methods and Applications. M. A. Innis, D. H. Gelfand, J. J. Sninsky, and T. J. White, eds. Academic Press, San Diego, CA.

64. White, C., Halleen, F., and Mostert, L. 2011. Symptoms and fungi associated with esca in South Africa. Phytopathol. Mediterr. 50:S236-S246.

65. Willison, R. S., Chamberlain, G. C., Townshend, J. L., and de Ronde, J. H 1965. Epidemiology and control of dead-arm disease of grapes. Can. J. Bot. 43:901-914. 